\title{
A Simple Inoculation Method with a Single Resting Spore of Plasmodiophora brassicae
}

\author{
Koji KAGEYAMA*, Yoriko KAMIMURA** and Mitsuro HyaKUmaCHI*
}

\begin{abstract}
Single inoculation method using a single resting spore of Plasmodiophora brassicae was developed. Single resting spore was obtained by placing a $0.5 \mu 1$ drop of spore suspension, which was adjusted to the concentration of 2000 spores per $\mathrm{ml}$, on a piece of sterilized cover glass with a micropipette. The drop was checked under an inverted microscope to ensure that it exactly carried one spore alone. The cover glass carrying a single spore was placed on the surface of autoclaved soil in a pot. One- or two-day-old seedling of Chinese cabbage was inoculated by placing over the spore drop, covered with a small amount of soil, and grown in a growth chamber. The inoculation method could give an efficient infection. Pathogenicity of the single-spore isolates obtained was compared with their original populations to the host lines of European Clubroot Differential set, and was not always identical in those combinations.
\end{abstract}

(Received September 9, 1994; Accepted March 20, 1995)

Key words : crucifers, Plasmodiophora brassicae, single-resting-spore inoculation.

\section{INTRODUCTION}

Clubroot disease, caused by Plasmodiophora brassicae Wor., is one of the most important diseases of cruciferous plants and breeding for resistant cultivars is in progress. It is suggested, however, that a wild population of $P$. brassicae consists of some pathotypes even in a field plot or within a gall tissue ${ }^{3,4,13}$. Accordingly, single spore isolation is essential for purification of pathotypes. The trial, however, has been difficult since $P$. brassicae cannot be artificially cultured, except for callus culture of infected host tissue with the pathogen ${ }^{4)}$. Although isolates have been obtained by inoculating seedlings with a single resting spore ${ }^{1,6,8,10)}$, the techniques were laborious and often failed to give a high success rate.

This paper describes studies for an improved and simplified method for producing shingle-spore isolates, and differential pathogenicity of the isolates.

\section{MATERIALS AND METHODS}

Isolation of single resting spores. Clubroot galls were collected from Prefectures of Aichi and Ibaraki in Japan, and the pathogens were designated as Toyohashi and Ibaraki populations, respectively. They were maintained and multiplied in highly susceptible Chinese cabbage, Brassica campestris L. var. chinensis (L.) Makino, cvs. Granaat (ECD line '05’) and Muso, or turnip, B. campestris var.rapifera Metz, cv. Taibyohikari by using common method of Williams ${ }^{12)}$. The clubroot tissues were recovered from the inoculated Chinese cabbage or turnip plants, followed by crushing in sterilized distilled water in a petri dish with tweezers. Resting spores were easily suspended when clubbed tissues were severely rotted. Spore suspension was filtered through 8 layers of gauze, and adjusted to the concentration of $2 \times$ $10^{3}$ spores $/ \mathrm{ml}$, so as to contain one single spore in $0.5 \mu 1$ of the suspension. A $0.5 \mu 1$ drop of the suspension was placed on a piece of sterilized cover glass with a micropipette. The drop was checked at least three times under an inverted microscope to ensure that it carried exactly one spore. The drop was added with one microliter of sterilized distilled water in order to prevent the spore from desiccation. The cover glasses with drops were transferred to petri dishes with moistened filter paper until employed.

Inoculation to plant with single spore. Seeds of Chinese cabbage (cvs. Muso or Granaat) and turnip (cv. Taibyohikari) were surface-sterilized by immersing in $70 \%$ ethanol for $c a .1 \mathrm{~min}$ and subsequent $0.5 \%$ sodium hypochlorite for $30 \mathrm{~min}$, and rinsed three times with sterilized distilled water. The seeds were placed in petri dishes with moistened filter paper and incubated at $25^{\circ} \mathrm{C}$ for 1 or 2 days. The cover glass carrying the single spore was placed on the surface of autoclaved soil with which a polycarbonate bottle $(6 \times 6 \times 10 \mathrm{~cm})$ was filled. The young seedling was placed over the drop on the cover glass, and covered with a small amount of potting soil,

* Faculty of Agriculture, Gifu University, Yanagido, Gifu 501-11, Japan 岐阜大学農学部

** Present address: National Institute of Agro-Environmental Science, Tsukuba 305, Japan 
named as the cover glass method. The bottles with the inoculated seedlings were covered with polypropylene lids for a week to keep humidity and to enhance infection with the pathogen. The seedlings were kept in a growth chamber at $25^{\circ} \mathrm{C}$ with a 16 -hr photoperiod for 3 weeks. The plants were then transferred to another growth chamber maintained at $20^{\circ} \mathrm{C}$ at night and $25^{\circ} \mathrm{C}$ in the daytime, and grown for a further 5 -weeks period. The gall formation on roots was graded with the scale from 0 (no clubs) to 3 ( severe swelling on lateral and tap roots) according to Naiki et $a l^{7)}$

Pathogenicity test. The host lines of European Clubroot Differential (ECD) set ${ }^{2}$ were used to compare pathogenicity between the single spore isolates and their original populations. ECD lines 01 or 04 were not used because all these hosts had never been attacked by Toyohashi and Ibaraki populations in the preliminary experiments. Inoculum level obtained from the galls which had been formed with the single spore inoculation was not enough to use to test pathogenicity because a large amount of inoculum is required to inoculate 11 host lines of ECD. Therefore, multiplication of inoculum was conducted by using cover glass method in which inoculum was obtained by crushing the galls with a mortar and a pestle. Host plants were inoculated by modifying the technique known as 'slurry method"11). Inoculum for pathogenicity test was obtained by macerating the multiplied galls, filtering the suspension through 8 layers of gauze and centrifuging the filtrate ${ }^{12)}$. The spore suspension was mixed with autoclaved soil $(1: 2, \mathrm{w} / \mathrm{w})$ to make slurry. The spore concentration in the slurry was adjusted to $0.3-3.0 \times 10^{6} / \mathrm{ml}$. On each pot $(5 \mathrm{~cm}$ in diam. and $10 \mathrm{~cm}$ high) containing autoclaved soil, a hole of 3 $\mathrm{cm}$ diam. and $2 \mathrm{~cm}$ deep was made with a centrifuge tube. Approximately $20 \mathrm{ml}$ of the slurry was poured into the hole in each pot, and 6 seedlings of one-day-old were immediately transplanted on the slurry. The pots were placed on trays filled with water up to $1-2 \mathrm{~cm}$ high and incubated on greenhouse benches. The number of plants per pot was thinned afterward to 5 plants. The test for each ECD line was replicated five times. The galls were graded 6 to 8 weeks after inoculation, as described in the preceding paragraph. The disease severity was calculated in the following. The number of plants in index 0 was multiplied by 0 , in index 1 by 10 , in index 2 by 80 , and in index 3 by 100 , and the sum was divided by the total number of plants.

\section{RESULTS}

\section{Gall formation with single-resting-spore inocula- tion}

Through thirteen trials of single spore inoculation, eight clubroot galls were successfully obtained (Table $1)$. Galls were formed in both Chinese cabbage and turnip, independently of the seedling age. Out of 8 , half of the galls formed were rated as index 3 , and the others showed less than $5 \mathrm{~mm}$ (Fig. 1). In the both cases more than one gall were developed on a plant.

\section{Differences in pathogenicity of single-resting- spore isolates}

Pathogenicity of five single-spore isolates multiplied was compared with the original populations (Table 2). In Toyohashi population, since the single-spore isolates were derived from the inoculum of either turnip or Chinese cabbage, the two hosts were employed for the corresponding comparison. All single-spore isolates (To1-To-6) gave similar results to their original population for all ECD lines tested. Isolate Ib-1 from Ibaraki population, however, differed from its original popula-

Table 1. Clubroot formation in Chinese cabbage and turnip inoculated with single spore of Toyohashi population of Plasmodiophora brassicae

\begin{tabular}{|c|c|c|c|c|c|c|c|c|c|}
\hline \multirow{3}{*}{ Host } & \multirow{3}{*}{ Cultivar } & \multirow{3}{*}{$\begin{array}{c}\text { Time of } \\
\text { incubation }^{\text {a) }}\end{array}$} & \multirow{3}{*}{ Replication } & \multicolumn{6}{|c|}{ No. of plants } \\
\hline & & & & \multirow{2}{*}{ Tested } & \multirow{2}{*}{ Dead $^{\text {b) }}$} & \multicolumn{4}{|c|}{ Disease index ${ }^{c)}$} \\
\hline & & & & & & 0 & 1 & 2 & 3 \\
\hline \multirow[t]{10}{*}{ Chinese cabbage } & Granaat & $24 \mathrm{hr}$ & 1 & 10 & 0 & 10 & 0 & 0 & 0 \\
\hline & Muso & $24 \mathrm{hr}$ & 1 & 9 & 0 & 7 & 2 & 0 & 0 \\
\hline & & & 2 & 10 & 0 & 10 & 0 & 0 & 0 \\
\hline & & & 4 & 9 & 0 & 8 & 1 & 0 & 0 \\
\hline & & & 5 & 9 & 1 & 8 & 0 & 0 & 0 \\
\hline & & & 6 & 8 & 0 & 8 & 0 & 0 & 0 \\
\hline & & & 7 & 10 & 0 & 10 & 0 & 0 & 0 \\
\hline & Muso & $48 \mathrm{hr}$ & 1 & 8 & 0 & 7 & 0 & 0 & 1 \\
\hline & & & 2 & 14 & 0 & 14 & 0 & 0 & 0 \\
\hline & & & 3 & 12 & 0 & 10 & 1 & 0 & 1 \\
\hline Turnip & & & 2 & 10 & 0 & 10 & 0 & 0 & 0 \\
\hline
\end{tabular}

a) Seeds were germinated in a moist petri dish at $25^{\circ} \mathrm{C}$ in the dark.

b) Non-emerging and dead plants.

c) Disease index was based on the scale of 0 (no clubs) to 3 (severe swelling on lateral and tap roots). 
Table 2. Pathogenicity of single spore isolates and their original population of Plasmodiophora brassicae to European Clubroot Differential (ECD) hosts

\begin{tabular}{|c|c|c|c|c|c|c|c|c|}
\hline \multirow{3}{*}{ ECD host } & \multicolumn{6}{|c|}{ Toyohashi population } & \multirow{2}{*}{\multicolumn{2}{|c|}{$\begin{array}{l}\text { Ibaraki population } \\
\text { Chinese cabbage }^{\text {a) }}\end{array}$}} \\
\hline & \multicolumn{2}{|c|}{ Turnip ${ }^{\text {a) }}$} & \multicolumn{4}{|c|}{ Chinese cabbage $^{\text {a) }}$} & & \\
\hline & To-1 & Original & To-2 & To-4 & To-6 & Original & Ib-1 & Original \\
\hline \multicolumn{9}{|l|}{ Brassicae campestris } \\
\hline 05 & 100 & 100 & 100 & 95 & 98 & 100 & 100 & 100 \\
\hline \multicolumn{9}{|l|}{ B. napus } \\
\hline 06 & 100 & 100 & 93 & 98 & 98 & 100 & 98 & 100 \\
\hline 07 & 100 & 99 & 97 & 96 & 98 & 100 & 100 & 100 \\
\hline 08 & 100 & 100 & 100 & 96 & 99 & 100 & 100 & 100 \\
\hline 09 & 98 & 100 & 85 & 86 & 95 & 98 & 97 & 100 \\
\hline 10 & 17 & 19 & 12 & 18 & 20 & 15 & 11 & 27 \\
\hline \multicolumn{9}{|l|}{ B. oleracea } \\
\hline 11 & 19 & 19 & 42 & 27 & 39 & 27 & 29 & 49 \\
\hline 12 & 26 & -b) & 35 & 27 & 28 & 29 & 17 & 75 \\
\hline 13 & 58 & - & 53 & 62 & 63 & 67 & 66 & 63 \\
\hline 14 & 87 & - & 96 & 95 & 84 & 97 & 97 & 100 \\
\hline 15 & 22 & - & 23 & 30 & 25 & 30 & 18 & 22 \\
\hline
\end{tabular}

a) Inoculum tested was multiplied with turnip or Chinese cabbage.

b) Not tested.

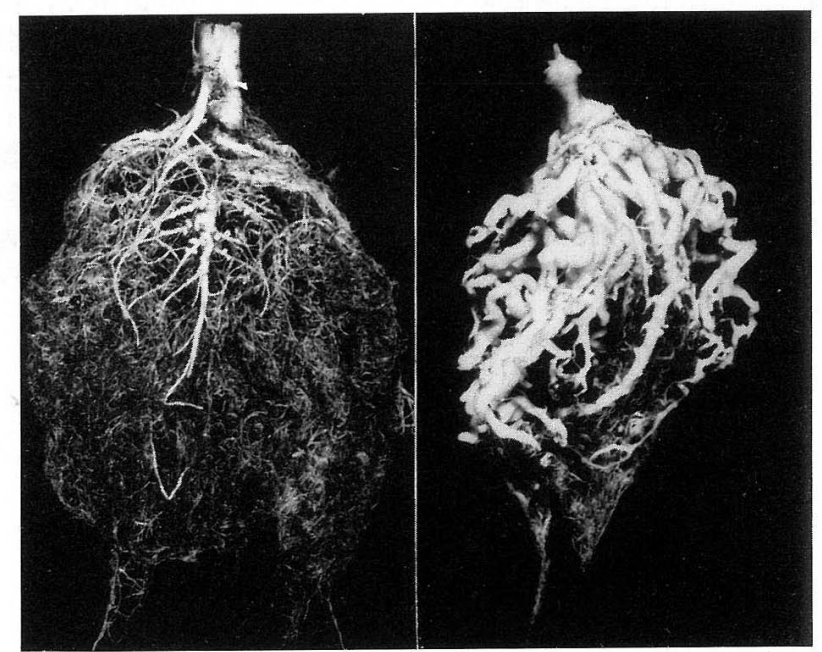

Fig. 1. The galls formed on the roots of Brassica campestris var. chinensis cv. Muso by inoculation with single resting spore of Plasmodiophora brassicae. Right: disease index 3; left: index 1.

tion in pathogencity; the isolate caused apparently lower disease to ECD line 12, although the other ECD lines the disease severity was similar.

\section{DISCUSSION}

Two technical problems may exist in single spore inoculation; one is to isolate single spores and the other to inoculate to host seedlings with the isolated spores. Reports $^{6,8)}$ suggested the importance to use mature spores with high viability. Suzuki et al. ( $^{9}$ demonstrated that resting spores in rotten galls were highly germinative, and therefore such galls were employed in the present study. In order to isolate single spores, Tinggal $\& W_{\text {Webster }}{ }^{10)}$, Jones et $a l .{ }^{6)}$ and Scott ${ }^{8)}$ used the special instruments, such as a dummy microscope objective lens on which a punch was mounted to cut and lift out a disc of agar with a single spore. In our study, only an inverted microscope and a micropipette are needed. The technique is simple and not laborious; at least 4 single spores per hour could be isolated. Our procedure is similar to the paraffin drop method proposed by Buczacki ${ }^{1)}$, but paraffin has an inhibitory effect on germination and infection of spores, according to Tinggal and Webster ${ }^{10}$.

The present cover glass method has an advantage that the seedlings employed rarely lose the single resting spores applied. The method gave the same levels of infection as Tinggal and Webster ${ }^{10)}$, and proved effective several times as much as Buczacki ${ }^{1)}$, Jones et al. ${ }^{6}$ and $\mathrm{Scott}^{8}$. Furthermore, the method was applicable for efficient multiplication of the inoculum from small galls obtained by the single spore inoculation.

In Ibaraki population, the single spore isolate differed from its original population in pathogenicity to ECD line 12. Wit \& Weg $^{13)}$ and Jones et al. ${ }^{5)}$ suggested that a pathogen population from a field plot or even in a single clubroot gall was heterogeneous in pathogenicity. The studies of single spore isolation ${ }^{6,8,10)}$ clearly proved that the field population included some variations with different pathotypes. The present results confirmed the pathogenic heterogeneity in populations of $P$. brassicae in Japan.

\section{Literature cited}

1. Buczacki, S.T. (1977). Root infections from single resting spores of Plasmodiophora brassicae. Trans. Br. 
Mycol. Soc. 69 : 328-329.

2. Buczacki, S.T., Toxopeus, H., Mattusch, P., Johnston, T.D., Dixon, G.R. and Hobolth, L.A. (1975). Study of physiologic specialization in Plasmodiophora brassicae: Proposals for attempted rationalization through an international approach. Trans. Br. Mycol. Soc. 65 : 259303.

3. Dixon, D.R. (1986). Variation in Plasmodiophora brassicae. Ann. Appl. Biol. 94 : 278-280.

4. Ikegami, H. and Mukobata, H. (1990). Growth on medium of Plasmodiophora brassicae infected callus tissue (Studies on the clubroot of cruciferous plants IX) Res. Bull. Fac. Agr. Gifu Univ. 55 : 1-14.

5. Jones, D.R., Ingram, D.S. and Dixon, G.R. (1982). Factors affecting tests for differential pathogenicity in populations of Plasmodiophora brassicae. Plant Pathol. $31: 229-238$.

6. Jones, D.R., Ingram, D.S. and Dixon, G.R. (1982). Characterization of isolates derived from single resting spores of Plasmodiophora brassicae and studies of their interaction. Plant Pathol. 31 : 239-246.

7. Naiki, T., Kageyama, K. and Ikegami, H. (1978). The relation of spore density of Plasmodiophora brassicae Wor. to the root hair infection and club formation in Chinese cabbage (Studies on the clubroot of cruciferous plant II). Ann. Phytopathol. Soc. Jpn. 44 : 432-439.

8. Scott, E.S. (1985). Production and characterization of single-spore isolates of Plasmodiophora brassicae. Plant Pathol. 34 : 287-292.

9. Suzuki, K., Matsumiya, E., Ueno, Y. and Mizutani, J. (1992). Some properties of germination-stimulating factor from plants for resting spores of Plasmodiophora brassicae. Ann. Phytopathol. Soc. Jpn. 58: 699-705.

10. Tinggal, S.H. and Webster, J. (1981). Technique for single spore infection by Plasmodiophora brassicae. Trans. Br. Mycol. Soc. 76 : 187-190.

11. Toxopeus, H. and Janssen, A.M.P. (1975). Clubroot resistance in turnip. II. The 'slurry' screening method and clubroot races in the Netherlands. Euphytica 24: 751-755.

12. Williams, P.H. (1965). A system for the determination of races of Plasmodiophora brassicae that infect cabbage and rutabaga. Phytopathology $56: 624-626$.

13. Wit, F. and Weg, M., var der (1964). Clubrootresistance in turnips (Brassica campestris L.). Euphytica $13: 9-18$

\section{和 文 摘 要}

景山幸二・上村順子・百町満朗：アブラナ科野菜根こぶ病菌 の単一休眠胞子による簡便な接種法

アブラナ科野菜根こぶ病菌の単一の休眠胞子を感受性宿主に 接種することにより発病させる簡便な技術を開発した。 $0.5 \mu l$ 当たり 1 個，すなわち $1 \mathrm{ml}$ 当たり 2000 個の濃度になるように 調整した休眠胞子懸濁液をマイクロピペットで $0.5 \mu 1$ 取り, 殺 菌したカバーグラス上に滴下した。この液の中に 1 個の休眠胞 子が含まれることを倒立顕微鏡で確かめ，カバーグラスを高圧 蒸気滅菌した育苗培養土上に置き, 2 日間催芽させた八クサイ の苗を液に接するように載せて軽く覆土し, 人工気象器内で栽 培した。この方法により高率に根こぶを形成させることができ た。欧州判別品種を用いて単一休眠胞子由来株とその元株で病 原性を比較したところ, 両者が異なる場合があることが認めら れた。 